Article

\title{
Design and Implementation of a Smart System to Control Aromatic Herb Dehydration Process
}

\author{
Pietro Catania, Raimondo Gaglio, Santo Orlando *(D), Luca Settanni ${ }^{\circledR}$ and Mariangela Vallone \\ Department of Agricultural, Food and Forest Sciences (SAAF), University of Palermo, viale delle Scienze ed. 4, \\ 90128 Palermo, Italy; pietro.catania@unipa.it (P.C.); raimondo.gaglio@unipa.it (R.G.); \\ luca.settanni@unipa.it (L.S.); mariangela.vallone@unipa.it (M.V.) \\ * Correspondence: santo.orlando@unipa.it
}

Received: 18 June 2020; Accepted: 3 August 2020; Published: 5 August 2020

check for

updates

\begin{abstract}
Drying is a process aimed at reducing the water content in plant materials below a limit where the activity of microbes and decomposing enzymes deteriorate the quality of medicinal and aromatic plants. Today, the interest of consumers towards medicinal and aromatic herbs has registered a growing trend. This study aims at designing a low-cost real-time monitoring and control system for the drying process of aromatic herbs and evaluating drying efficacy on the microbial community associated with the studied herbs. Hot-air drying tests of sage and laurel leaves were carried out in a dryer desiccator cabinet at $40{ }^{\circ} \mathrm{C}$ and $25 \%$ relative humidity using three biomass densities $\left(3,4\right.$ and $\left.5 \mathrm{~kg} / \mathrm{m}^{2}\right)$. The prototype of the smart system is based on an Arduino Mega 2560 board, to which nine Siemens 7MH5102-1PD00 load cells and a DHT22 temperature and humidity sensor were added. The data acquired by the sensors were transmitted through Wi-Fi to a ThingSpeak account in order to monitor the drying process in real time. The variation in the moisture content of the product and the drying rate were obtained. The system provided a valid support decision during the drying process, allowing for the precise monitoring of the evolution of the biomass moisture loss and drying rate for laurel and sage. The three different biomass densities employed did not provide significant differences in the drying process for sage. Statistically significant differences among the three tests were found for laurel in the final part of the process. The microbial loads of the aromatic herbs after drying were influenced by the different leaf structures of the species; in particular, with laurel leaves, microbial survival increased with increasing biomass density. Finally, with the drying method adopted, the two species under consideration showed a different microbial stability and, consequently, had a different shelf life, longer for sage than laurel, as also confirmed by water activity $\left(\mathrm{a}_{\mathrm{W}}\right)$ values.
\end{abstract}

Keywords: laurel; microbial load; oven drying; real time monitoring; sage; sensor

\section{Introduction}

In the last few years, the interest of consumers towards aromatic and medicinal herbs has registered a growing trend both in terms of product types and consumption [1]. In the past, these plants mainly concerned the derivatives and ingredients industries, while today we are witnessing a growing use in different sectors, such as functional food (nutraceutics) or infusion drinks (herbal teas) and bio-ecological cosmetics [2].

Plants from historical times are applied for fitness in addition to the supply of drug treatments; regarding the fact that $80-85 \%$ of the world-wide population depends on ancient medicines [3-5]. Furthermore, since ancient times, aromatic plants have been used in food preparation, not only to ameliorate the taste and flavor of the final products, but also as preservatives, due to their antimicrobial properties [6,7]. 
At least 2000 species of medicinal and aromatic plants are marketed in Europe. Italy has a contributes to $3 \%$ of overall European production. Italian imports are around 161 thousand tons with an outlay of around USD 1.14 billion. The Italian production of medicinal plants satisfies only $30 \%$ of the national needs, the remaining $70 \%$ of the herbs consumed in our country come from abroad; in particular, from countries of Eastern Europe and North Africa, but their cultivation is certainly expanding [8].

The cultivation of aromatic plants has many similarities with the cultivation of horticultural species in the open field and, therefore, a fairly intensive cultivation system, which provides for planting, frequent cultivation care and one or more harvests during the development cycle of the crop in the production season. The plants are harvested in the green field, in bloom. When the parts mature, except for a few and rare cases, they are a product that contain variable percentages of vegetation water and, therefore, cannot be conserved and transported, except in a short range. Harvesting can be done by hand or by machine, depending on the type of crop and the characteristics of the farm.

Once harvested, the biomass has a short life, from a few hours to a maximum of half a day. It needs immediate processing or stabilization. After harvesting, primary processes for the product to be marketed are required. These processes are specific to the type of farm and production chain - that is, each company definitively chooses its own basic production orientation: dried, essential oils, or fresh [9].

Drying is a process that consists in reducing the water content of the product below a value that limits the microbiological and enzymatic reactions responsible for its deterioration [10]. In addition to traditional methods, plants can be dried by automated methods with stoves or dryers.

Artificial drying is necessary in industrial production. It allows for drying a large quantity of material in a short time (24-48 h), always using low temperatures below $50{ }^{\circ} \mathrm{C}$ with an optimum of $40{ }^{\circ} \mathrm{C}$ [11-13]. It is a very expensive system both from an energy and an economic point of view, also affecting up to $50 \%$ of the production cost of the dry plant [14-17].

During the drying process, the aromatic herbs are subjected to chemical and physical changes that influence the quality of the finished product. The extent of these changes mainly depends on the drying conditions and the biological characteristics of the herbs [18].

The principle is to dry the free waters with a forced flow of dry air, passed through the biomass, spread over large surfaces on one or more layers. Hot-air drying, using convective ovens, is a fundamental technology for the postharvest preservation of aromatic and medicinal plants in non-tropical countries, since it allows a fully controlled operation, resulting in a desired end product. The most essential parameter influencing the end product quality of dried herbs is the temperature used [19].

In general, hot-air drying can lead to a drastic reduction in the quality of the end product compared to the original foodstuff [20]; principally high temperature causes the decomposition of bioactive ingredients and changes in colorful components [21,22]. On the other hand, drying at $35-50{ }^{\circ} \mathrm{C}$ allows for the preservation of heat-sensitive compounds $[23,24]$. In addition, high temperature has been used successfully to decrease the concentration of toxic compounds or reduce adverse taste characteristics in dried herbs. The main disadvantages of hot-air drying are the excessive shrinkage that is sometimes observed, color changes and overall product collapsing.

The consulted literature sources show that the optimal temperature to be used in the dehydration processes of aromatic herbs through the use of oven-drying is in the range of $40-45^{\circ} \mathrm{C}$. In fact, Diaz-Maroto et al. [11] confirm that by drying laurel leaves at $45^{\circ} \mathrm{C}$, the losses of volatile compounds are negligible compared to air drying, and Hadjibagher Kandi and Sefidkon [12] stated that, to obtain the highest yield value in essential oil from laurel leaves, the best drying method is oven-drying at $40{ }^{\circ} \mathrm{C}$. Sadowska et al. [13] found that, by drying sage at $40{ }^{\circ} \mathrm{C}$, polyphenols content and antioxidant activity did not show statistically significant differences compared to the values obtained with the naturally dry method. 
From these studies, it appears that temperature control during the drying process is of fundamental importance for the quality of the final product. In fact, in recent years numerous studies have been carried out on the application of modern systems to control and monitor the main environmental parameters [25-27].

The aim of this study was the design of a low-cost real-time monitoring and control system for the drying process of aromatic herbs inside a dryer desiccator cabinet. During the process and at the end, microbiological analyses were carried out on biomass samples to evaluate the stability achieved in the dried product.

\section{Materials and Methods}

\subsection{Plant Material}

The texts were carried out in June 2019. The biomass was harvested from plants of the campus area of the Department of Agricultural, Food and Forest Sciences, University of Palermo, Italy (N $38^{\circ} 06^{\prime} 28^{\prime \prime}$, $\mathrm{E} 13^{\circ} 21^{\prime} 00^{\prime \prime}, 31 \mathrm{~m}$ asl), where two experimental plots were selected $(20 \mathrm{~m} \times 20 \mathrm{~m}$ each). The climate of the area is Mediterranean with mild and humid winters and hot and dry summers; the climate is classified as Csa, according to Köppen and Geiger (hot-summer Mediterranean climate). The average temperature is $18.4{ }^{\circ} \mathrm{C}$ and the average annual rainfall is $605 \mathrm{~mm}$. The soils have a sandy clay texture (Aric Regosol, $54 \%$ sand, $23 \%$ silt and $23 \%$ clay) with a pH of $7.6,14 \mathrm{~g} \mathrm{~kg}^{-1}$ organic matter, $3.70 \%$ active limestone [28].

The sage (Salvia officinalis L.) was taken from 5 year-old plants, with a shrubby creeping habitus in a planting layout of $1 \times 2 \mathrm{~m}$; the apical leaves were collected using scissors.

The laurel (Laurus nobilis L.) plants had a shrub habitus, were $1 \mathrm{~m}$ high, 5 years-old, and had a planting lay out of $1 \times 2 \mathrm{~m}$. Using pruning shears, 1-2 year-old branches with leaves of about $0.30-0.40 \mathrm{~m}$ long, were taken.

The collected material was immediately transported to the laboratory, placed in polyethylene vented crates and put inside the drying chamber after about $1 \mathrm{~h}$ from harvest.

\subsection{Drying}

Hot-air drying tests of sage and laurel leaves were carried out in a dryer desiccator cabinet (KW Apparecchi Scientifici s.r.l, Italy). The cabinet is entirely made of AISI 304 stainless steel, it has $95 \times 60 \times 150 \mathrm{~cm}$ internal dimensions, equipped with two split opening doors with sealing. It is $1250 \mathrm{~W}$ powered and the temperature ranges from $+5^{\circ} \mathrm{C}$ above ambient temperature to $130^{\circ} \mathrm{C}$, controlled by means of a thermostat. The dryer desiccator cabinet is also equipped with a ventilation system to control relative humidity. Heating is achieved with specific air heaters with ascending flow to facilitate the evacuation of vapors. The steam discharge inside the chamber occurs by means of a centrifugal electro-aspirator with $40 \mathrm{~m}^{3} / \mathrm{h}$ flow rate, placed in the upper part of the cabinet.

Three biomass densities $\left(\mathrm{kg} / \mathrm{m}^{2}\right)$ were used for each species. The tests, named 1, 2 and 3, respectively, with biomass densities of 3,4 and $5 \mathrm{~kg} / \mathrm{m}^{2}$, were placed inside the shelves of the cabinet using polypropylene vented crates (dimensions $40 \times 60 \times 22 \mathrm{~cm}, 52 \mathrm{~L}$ capacity, $62 \%$ hollow surface). Three replicates for each test, named A, B and C, were randomly arranged inside the drying chamber (Figure 1). This was possible because the drying chamber was equipped with an automatic heating and ventilation system that guarantees to maintain both constant temperature and relative humidity inside, and because the contact surface between the biomass and the air inside the chamber was the same in the different tests. 


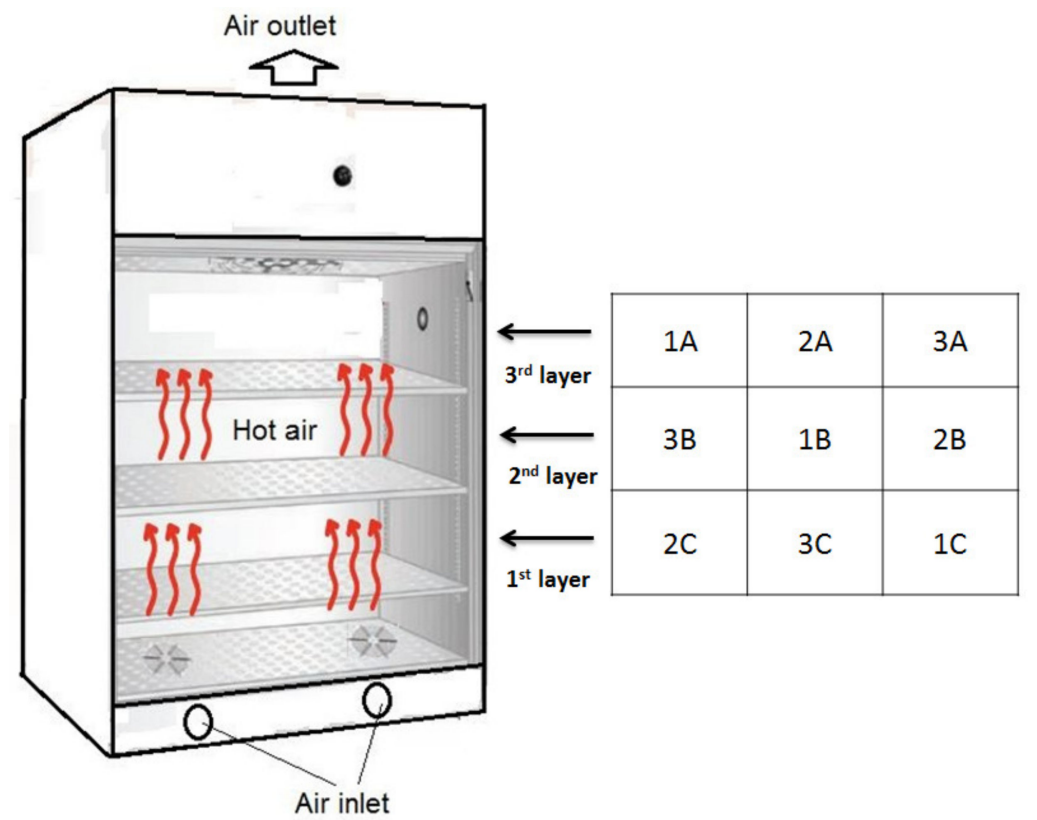

Figure 1. Scheme of the drying chamber and test repetitions.

After preheating the dryer desiccator cabinet, the drying temperature was maintained constant at $40{ }^{\circ} \mathrm{C}$ since a higher temperature may result in a darkening of the samples due to non-enzymatic browning and leading to a loss of quality. Relative humidity was kept at $25 \%$ for the entire duration of the process [18].

Overall, about $30 \mathrm{~kg}$ of leaves were taken to carry out the tests, $15 \mathrm{~kg}$ of sage and $15 \mathrm{~kg}$ of laurel. A sample of leaves was brought to the laboratory for the determination of the dry weight of each species. Dry weight was determined by weighing $10 \mathrm{~g}$ of herb samples and drying until a constant weight at $105^{\circ} \mathrm{C}$ in the drying oven (Termaks TS 800, Norway). The initial moisture content of sage was found to be $73.2 \pm 0.6 \%$ (wet basis); for laurel it was found to be $55.3 \pm 0.5 \%$ (wet basis). Water activity $\left(\mathrm{a}_{\mathrm{w}}\right.$ ) was measured to evaluate microbiological stability using a Rotronic Hygropalm HC2-AW (Rotronic AG, Bassersdorf, Switzerland), both on fresh and dried herbs (i.e., before and after dehydration).

The variation in the moisture content of the product during drying was experimentally determined through the evaluation of the following parameters.

The moisture content at time $\mathrm{t} M C_{t}[\%]$ was calculated as:

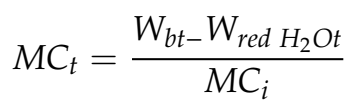

where: $W_{b t}$ is the normalized biomass weight $[\mathrm{g}]$ at time $t[\mathrm{~h}] ; \mathrm{W}_{\text {red } \mathrm{H}_{2} \mathrm{O} t}$ is the reduced water weight [g] at time $t[\mathrm{~h}] ; M C_{i}$ is the initial biomass moisture content $[\mathrm{g}]$.

The drying rate at time $t, D R_{t}\left[\mathrm{~g} / \mathrm{g} \mathrm{h}^{-1}\right]$ was then calculated as:

$$
D R_{t}=\frac{W_{\text {red } \mathrm{H}_{2} \mathrm{O} t}}{W_{b t}} t^{-1}
$$

The experimentally obtained curves for $M C_{t}$ and $D R_{t}$ are the variation during drying of the moisture content of the product and the drying rate as a function of time.

The end of drying was defined when the biomass weight remained stable for more than $10 \mathrm{~min}$ and the moisture content was lower than $14 \%$ for sage and $32 \%$ for laurel. 


\subsection{Smart Sensors System Structure}

The system is based on sensors capable of real time monitoring the biomass weight of the individual samples and temperature and relative humidity inside the drying chamber.

The choice of the components to be used in the realization of the prototype of the biomass drying measuring system was based on low-cost, reliable and small-sized components, which can be assembled inside the cabinet with the plastic boxes used to hold the sage and laurel samples. The system is based on an Arduino Mega 2560 board which, thanks to the large availability of inputs/outputs, allowed for the connection of (Figure 2):

- Five HX711 modules that power, amplify and convert to digital signal of the nine load cells;

- A DS3231 Real Time Clock (RTC) module that provides the system with the year, month, day, hours, minutes and seconds time reference;

- An ESP8266-05 module to transmit, through Wi-Fi, the data acquired by the various sensors to a ThingSpeak account every 15 min;

- A DHT22 sensor that allows for the detection of relative humidity and ambient temperature and to digitally transmit it to a micro-controller;

- Nine Siemens 7MH5102-1PD00 load cells capable of measuring static loads with medium precision with a maximum capacity of $5 \mathrm{~kg}$;

- A Serial OpenLog module that allows the acquired data to be stored on a microSD card in the form of appropriately structured strings, so as to contain the data of the individual sensors in the various fields (e.g., Data/Time; Sensor 1; Sensor 2; . . . . ; Sensor N), and transmitted from Arduino Mega serial output 2. This represents a security system that, even in the absence of a Wi-Fi connection, allows data recording from the sensors.

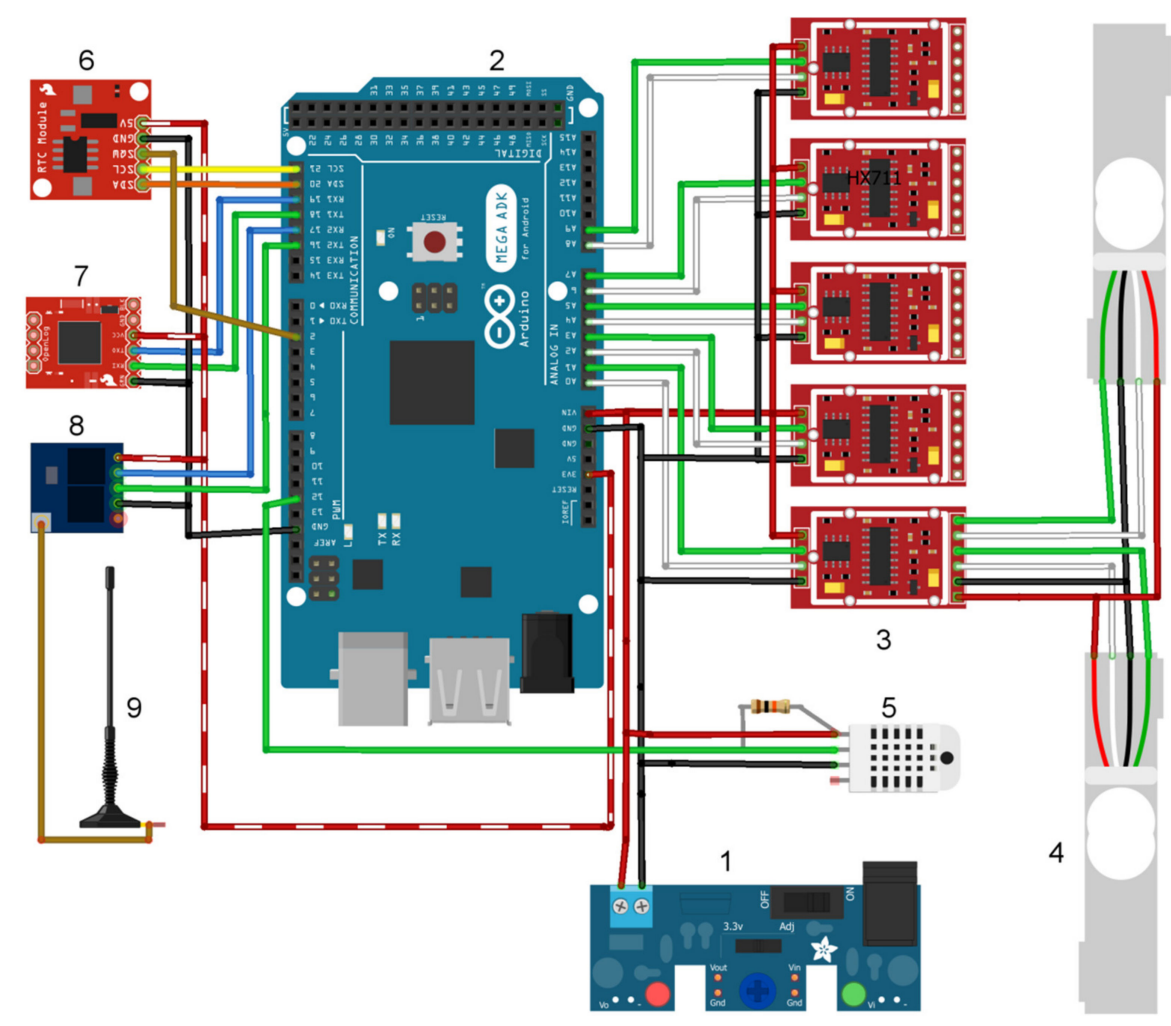

Figure 2. Smart sensors system structure. 1: Power supply; 2: Arduino Mega 2560 R3; 3: Load Cell Amplifier HX711; 4: Load Cell; 5: Digital temperature and humidity sensor DHT22; 6: Real- time clock DS3231; 7: OpenLog Data Logger; 8: Transceiver Wireless Module ESP8266-05; 9: External antenna. 
Arduino Mega 2560 R3 is a module based on the ATmega2560 microcontroller, which can be programmed using the Arduino IDE through the USB interface, which also acts as a power connection.

This card provides developers of simple embedded systems with a fast prototyping tool, thanks to the discrete calculation power and to the possibility of being interfaced with other cards or sensors through the different inputs and outputs available (54 I/O Digital Pin and 16 Analog Inputs Pin), allowing for the rapid creation of relatively complex systems. In fact, the Arduino Mega choice as a micro-controller was dictated by the need to use the numerous I/O pins available to simultaneously acquire the weight of the different medicinal herb samples placed in the cabinet, as well as temperature and relative humidity.

The specifications of the components used are:

- $\quad$ A/D converter module: Based on the HX711 chip, it is a 24-bit Analog-to-Digital Converter (ADC) for weighing scales specifically designed to interface the load cells, which exploit the Wheatstone bridge, to a microcontroller, such as Arduino or another that is compatible. It is also intended for process control applications. The module has two differentiated input channels, selectable through a multiplexer: a programmable and low noise gain amplifier allowing for the selection of the gain at 32, 64 and 128; a load cell on-chip power regulator; an analog ADC power supply; an on-chip oscillator that requires no external component intervention with external crystal. Since the output signal from a load cell is an analog signal proportional to the deformation of the cell, and is therefore proportional to the applied force, the signal is acquired through the analog to digital converter which reads the voltage difference in the Wheatstone bridge over the cells and then converts it into a 24-bit digital string, which can be acquired by a microcontroller (Arduino) via serial communication. The data are sampled at a frequency of $80 \mathrm{~Hz}$.

- $2 \mathrm{C}$ real time clock module (RTC): Based on the DS3231 chip, it is a low consumption clock/calendar that allows the Arduino to have a time reference to assign to the various analog samples acquired. Communication with the Arduino board takes place on the I2C serial bus, which is accessed in SLAVE mode. The time count is based on a $32 \mathrm{kHz}$ quartz oscillator, which ensures good accuracy.

- SP8266-05 module with external antenna: This is a Wi-Fi integrated SoC (system-on-a-chip) with a 32 bit LX106 Micro Controller Unit (MCU). It is a system suitable for providing Wi-Fi connectivity to an Arduino-like card but it is possible to use it to directly create IoT (Internet of Things) projects. As a simple Wi-Fi module, it is possible to manage it via AT commands and it is programmable with the Arduino IDE. It supports $802.11 \mathrm{~b} / \mathrm{g} / \mathrm{n}$ transmission protocols and Wi-Fi Direct (P2P) and soft-AP modes. It integrates the TR switch, the RF amplifier and the antenna, a PLL (power regulator).

- The DHT22 is a basic digital temperature and humidity sensor. It uses a capacitive humidity sensor and a thermistor to measure the surrounding air, and gives out a digital signal on the data pin, while no analog input pins are needed and the specifications are: 3 to $5 \mathrm{~V}$ power and $\mathrm{I} / \mathrm{O}$, $2.5 \mathrm{~mA}$ max current use during conversion (while requesting data), $0-100 \%$ relative humidity range with $2-5 \%$ accuracy, -40 to $80{ }^{\circ} \mathrm{C}$ temperature range $\pm 0.5{ }^{\circ} \mathrm{C}$ accuracy, $0.5 \mathrm{~Hz}$ maximum sampling rate (once every $2 \mathrm{~s}$ ), dimensions $15.1 \mathrm{~mm} \times 25 \mathrm{~mm} \times 7.7 \mathrm{~mm}, 4$ pins with $0.1^{\prime \prime}$ spacing.

- The single point, medium precision (class III) load cell-Siemens 7MH5102-1PD00—is designed for use in platform scales equipped with a single load cell. It is very easy to use and apply in a wide variety of applications, where the center of force acting is $62.5 \mathrm{~mm}$ from the vertical axis of the load cell. It offers good performance and very small dimensions $(25 \times 40 \times 150 \mathrm{~mm})$. The cell is made of aluminum and the recommended excitation voltage is between 5 and $12 \mathrm{~V} \mathrm{DC}$, while the output at nominal load is $2 \mathrm{mV} / \mathrm{V}$. It has an IP65 protection degree and allows 4 or 6 wire connections.

- Openlog module: A simple serial datalogger, based on an ATmega328 microprocessor clocked at $16 \mathrm{MHz}$, capable of handling large capacity microSD cards (up to $64 \mathrm{~GB}$ ) with FAT16 and FAT32. The main connection interface is FTDI type, with a configurable baud rate (up to 115,200 bps); 4 pins are also available for the SPI interface. 
All the electronic components are assembled inside a box from which only the power cables, connecting to the load cells and the external antenna, come out. Each load cell is fixed on one side on a stable steel support base, on the other side of a metal weighing plate. The whole system takes on a $\mathrm{Z}$ shape. Nine of them were realized and placed under each polypropylene vented crate containing the biomass samples inside the drying chamber.

\subsection{System Calibration and Data Processing}

For each individual cell, connected to its HX711 module, calibration was performed through 4 load conditions $(0,1.5,3$ and $5 \mathrm{~kg})$, which allowed us to determine the offset and compensation values of each individual sensor. Considering that the system had to work inside the dryer desiccator cabinet $\left(\approx 40{ }^{\circ} \mathrm{C}\right)$, the response of the sensor to three different temperature conditions $\left(10,25,40{ }^{\circ} \mathrm{C}\right)$ was also verified to assess the possible need for thermal compensation.

Using the Arduino IDE, a first calibration sketch was developed, which allowed us to determine the calibration factors subsequently inserted in the operating sketch. The acquisition of the values of weight, temperature and relative humidity was expected every $15 \mathrm{~min}$, as the respective average of a sample of 20 measurements, as well as the login parameters to the Wi-Fi network and the API keys for writing the data in the various ThingSpeak channels, were set up.

ThingSpeak is a cloud platform provided by Mathworks intended for IoT applications, capable of collecting, displaying and analyzing data from sensors in real time. In addition to allowing instantaneous displays of data from IoT devices, the platform can run MATLAB code on these data, for advanced "live" analysis and possibly for sending alerts.

After the complete assembly and the loading of the operating sketch, some tests were carried out to verify the correct functioning of the sensors, the transmission system (Wi-Fi and ThingSpeak) and data storage under operating conditions. To this end, the system and sensors were placed in the dryer desiccator cabinet and measurement tests were started. Metal loads were applied to the weighing plates and heating was started until the temperature reached $45^{\circ} \mathrm{C}$ was reached, keeping it constant for $48 \mathrm{~h}$. From the analysis of the data collected during these preliminary tests, no significant errors in the measurements emerged, both during the heating transient $\left(22-45^{\circ} \mathrm{C}\right)$ and during the steady state.

\subsection{Microbiological Analysis}

The microbial loads of sage and laurel were determined before and after each drying process. Ten grams of each herb sample were suspended in $90 \mathrm{~mL}$ of Ringer's solution (Sigma-Aldrich, Milan, Italy) and subjected to homogenization by means of the stomacher BagMixer ${ }^{\circledR} 400$ (Interscience, Saint Nom, France) for $2 \mathrm{~min}$ at the highest speed. The decimal serial dilutions of the cell suspensions were plated and incubated as follows: total mesophilic count (TMC) were spread plated on plate count agar (PCA), incubated aerobically at $30^{\circ} \mathrm{C}$ for $72 \mathrm{~h}$; members of the Enterobacteriaceae family were pour plated on double-layer violet red bile glucose agar (VRBGA), incubated aerobically at $37^{\circ} \mathrm{C}$ for $24 \mathrm{~h}$; total yeast spread plated on yeast extract peptone dextrose (YPD) nutrient agar incubated at $28^{\circ} \mathrm{C}$ for $48 \mathrm{~h}$; molds spread plated on malt agar (MA), incubated aerobically at $25^{\circ} \mathrm{C}$ for 7 days. To inhibit the growth of bacteria, chloramphenicol $(0.05 \mathrm{mg} / \mathrm{mL})$ was added to YPD and MA. Microbiological counts were performed in triplicate.

\subsection{Statistical Analysis}

The simple regression and the polynomial regression procedures were used to construct statistical models describing the impact of a single quantitative factor-that is time ( $\mathrm{t}$ ) in our study-on a dependent variable as the parameters moisture content (MC) and drying rate (DR) expressed through (1) and (2). A linear model involving $t$ or a polynomial model involving $t$ and powers of $t$ were considered appropriate to fit to the data. In addition, the analysis of variance (ANOVA) was considered in order to test if there were differences in the three biomass densities $\left(3,4\right.$ and $\left.5 \mathrm{~kg} / \mathrm{m}^{2}\right)$ in MC during time (a value every $6 \mathrm{~h}$ throughout the process was considered, named $\mathrm{t}_{0}, \mathrm{t}_{6}$, etc.). To test if there were 
statistical differences, Tukey's test was performed. Differences were considered significant at $5 \%$ level of significance.

Microbiological data were subjected to the one-way analysis of variance (ANOVA), too. The comparison of treatment means was achieved by Tukey's test; differences were considered significant at $5 \%$ level of significance.

All the analyses were performed with the statistical software package Statgraphics centurion, version XV (Statpoint Inc., The Plains, VA, USA, 2005).

\section{Results and Discussion}

\subsection{Dehydration Process}

The data continuously acquired by the drying process monitoring system are displayed through the ThingSpeak platform, which provides diagrams of the type shown in Figure 3, referring to a 24-h time span for three tests performed on the sage samples, in which the progressive weight decrease during drying is observed.
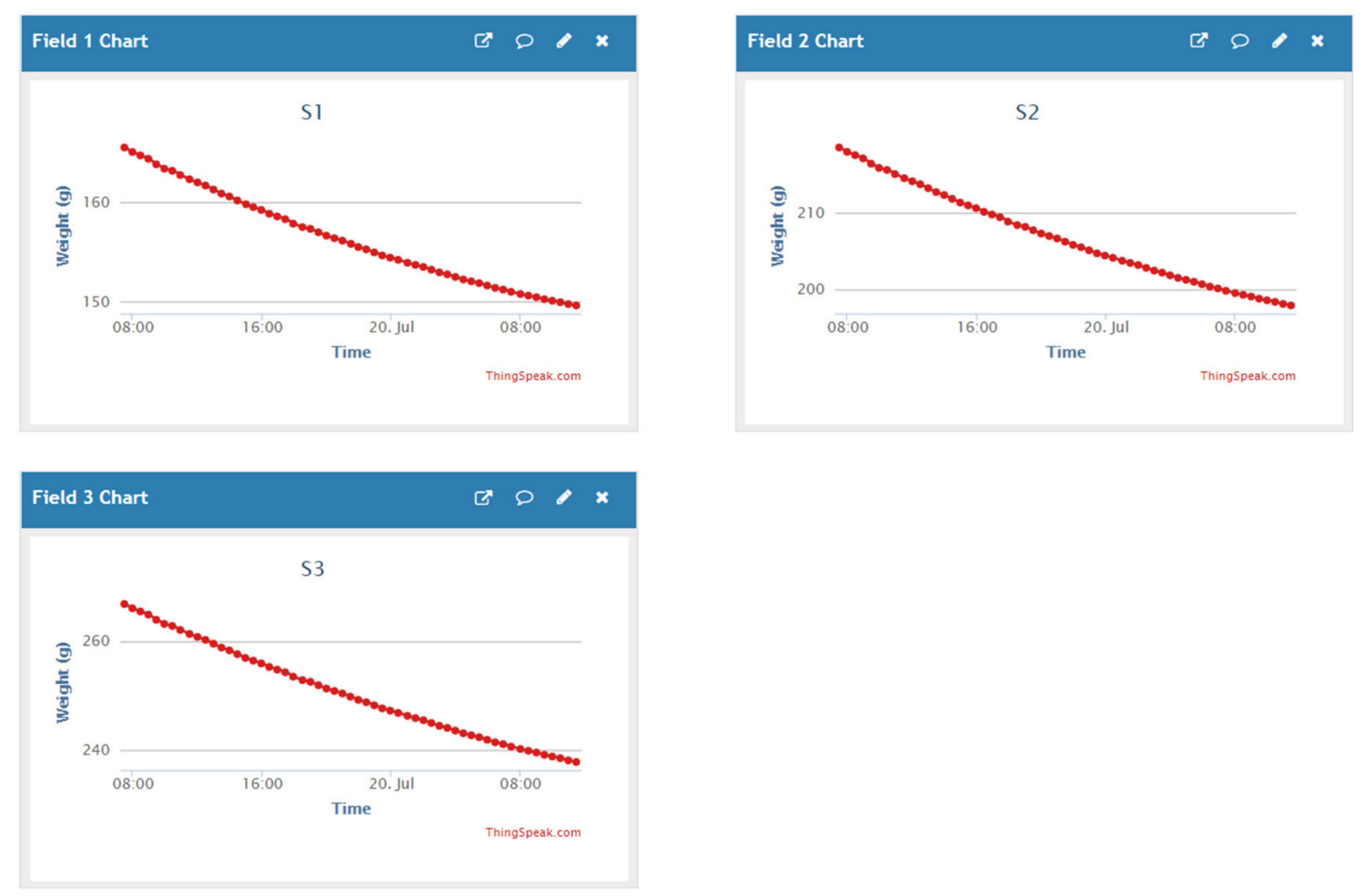

Figure 3. Example of real time data acquisition through ThingSpeak during the sage dehydration process for the three tests conditions $\left(\mathrm{S} 1=3 \mathrm{~kg} / \mathrm{m}^{2} ; \mathrm{S} 2=4 \mathrm{~kg} / \mathrm{m}^{2}\right.$ and $\left.\mathrm{S} 3=5 \mathrm{~kg} / \mathrm{m}^{2}\right)$.

The $a_{w}$ values of fresh and dried herbs are reported in Table 1. The dehydration process consistently reduced the availability of water for the microbial development in laurel and, especially, sage. Fresh herbs were characterized by $\mathrm{a}_{\mathrm{w}} 0.993$ and 0.968 (sage and laurel, respectively), which reduced during the drying process inversely to the biomass density with the lowest value $(0.335)$ shown by the trial S1 involving sage. The levels of $\mathrm{a}_{\mathrm{w}}$ after the drying of laurel were significantly higher (0.766 on average) than those showed by the corresponding biomass densities of sage, and this is undoubtedly imputable to the different leaf structure of the two aromatic plants. 
Table 1. Water activity $\left(\mathrm{a}_{\mathrm{w}}\right)$ values before and after dehydration.

\begin{tabular}{cccc}
\hline \multicolumn{2}{c}{ Sage } & \multicolumn{2}{c}{ Laurel } \\
\hline Test & $\mathbf{a}_{\mathbf{w}}$ & Test & $\mathbf{a}_{\mathbf{w}}$ \\
\hline Fresh & $0.993 \pm 0.001$ & Fresh & $0.968 \pm 0.001$ \\
S1 & $0.335 \pm 0.002$ & L1 & $0.679 \pm 0.001$ \\
S2 & $0.339 \pm 0.001$ & L2 & $0.787 \pm 0.003$ \\
S3 & $0.377 \pm 0.003$ & L3 & $0.831 \pm 0.002$ \\
\hline
\end{tabular}

The curves of the three biomass densities show a very similar trend (Figure $4 \mathrm{~A})$. The whole process has a total duration of $65 \mathrm{~h}$. The starting MC mean value is $73 \%$ and the final mean value is $13 \%$. In the first $14 \mathrm{~h}$ of the process, the curves relating to the three tests are overlapping. After $32 \mathrm{~h}$, halfway through the process, MC decreases about $59 \%$ of the total. These results are in agreement with those obtained in [29].

Figure 4 shows the progress of the sage dehydration process for the three biomass densities $\left(\mathrm{S} 1=3 \mathrm{~kg} / \mathrm{m}^{2} ; \mathrm{S} 2=4 \mathrm{~kg} / \mathrm{m}^{2}\right.$ and $\left.\mathrm{S} 3=5 \mathrm{~kg} / \mathrm{m}^{2}\right)$.

(A)

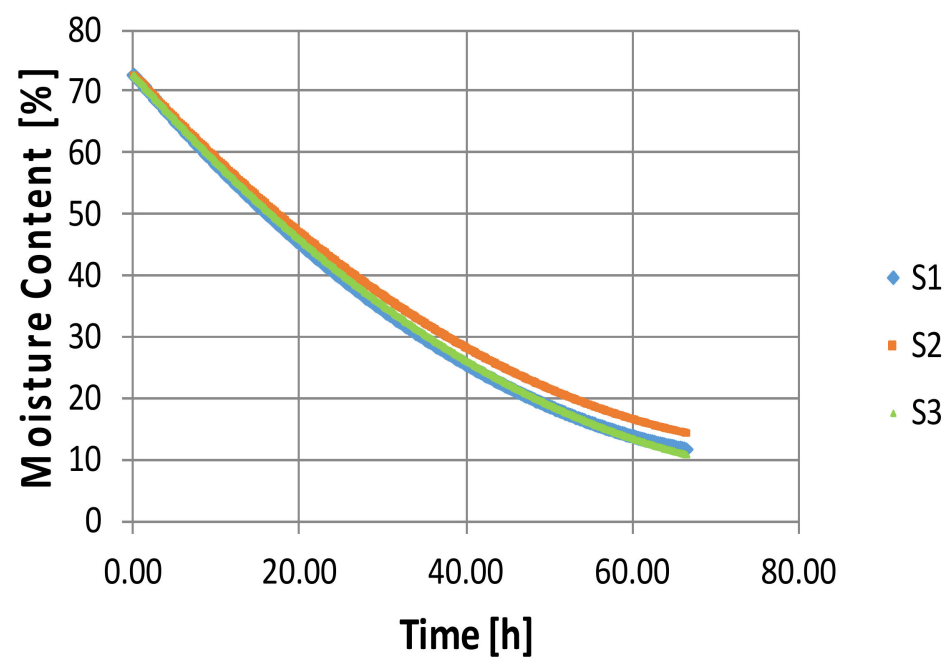

(B)

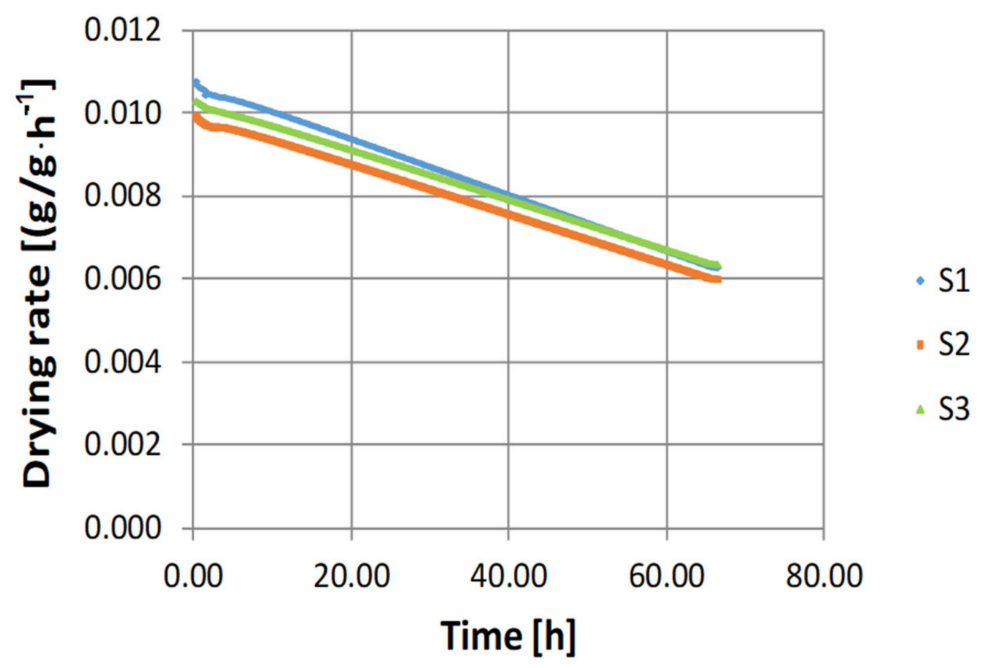

Figure 4. Curves of moisture content $M C_{t}(\mathbf{A})$ and drying rate $D R_{t}(\mathbf{B})$ as a function of time for sage dehydration process. Data are means of three replications $\left(\mathrm{S} 1=3 \mathrm{~kg} / \mathrm{m}^{2} ; \mathrm{S} 2=4 \mathrm{~kg} / \mathrm{m}^{2}\right.$ and $\left.\mathrm{S} 3=5 \mathrm{~kg} / \mathrm{m}^{2}\right)$. 
The MC value of dried sage at the end of the process represents the bound water and is reflected in the water activity value obtained after dehydration in the three tests.

As for the DR values obtained (Figure 4B), a falling drying rate trend can be observed, due to the difficulty of the capillary forces in transferring water from inside the tissues to the surface of the plant. DR starts from a value of $0.01 \mathrm{~g} / \mathrm{g} \mathrm{h}^{-1}$; then it constantly decreases, reaching the value of $0.006 \mathrm{~g} / \mathrm{g} \mathrm{h}^{-1}$ at the end of the process.

Regarding the laurel dehydration process, MC continuously decreases with the drying time (Figure 5A). The drying of laurel leaves takes more than $40 \mathrm{~h}$. Test L3 ends the dehydration process with a moisture content below $30 \%$, while tests $\mathrm{L} 1$ and L2 show an MC value higher than $30 \%$. In the first $10 \mathrm{~h}$ of the process, the curves related to the three tests are nearly coincident. After $20 \mathrm{~h}$, in the middle of the process, MC decreases by about $60 \%$ of the total value. The results obtained from this study are in agreement with those obtained in [30]. DR (Figure 5B) shows a sudden decrease in the first $3 \mathrm{~h}$ of the process, going from 0.02 to $0.01 \mathrm{~g} / \mathrm{g} \mathrm{h}^{-1}$. Then, the curves take on a horizontal trend up to half of the drying process. Starting from the 20th hour, in fact, there is a DR reduction up to the final

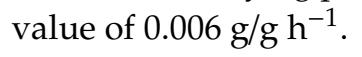

(A)

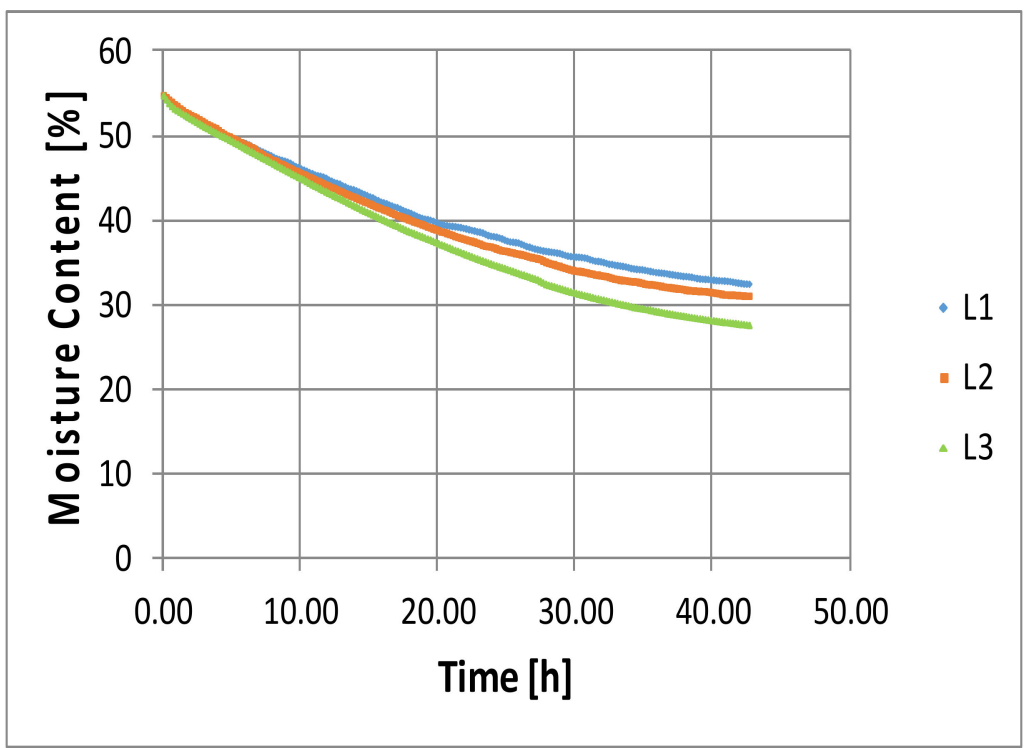

(B)

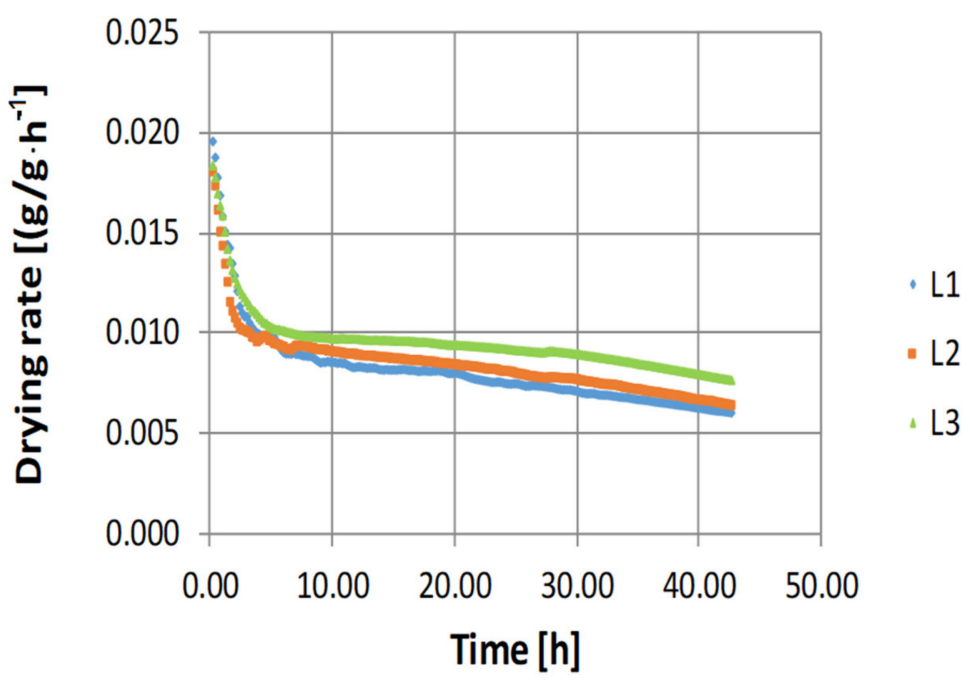

Figure 5. Curves of moisture content $M C_{t}(\mathbf{A})$ and drying rate $D R_{t}(\mathbf{B})$ as a function of time for laurel dehydration process. Data are means of three replications ( $\mathrm{L} 1=3 \mathrm{~kg} / \mathrm{m}^{2}, \mathrm{~L} 2=4 \mathrm{~kg} / \mathrm{m}^{2}$ and $\left.\mathrm{L} 3=5 \mathrm{~kg} / \mathrm{m}^{2}\right)$. 
The MC value of present dried laurel at the end of the process is reflected in the water activity obtained after dehydration, which was equal to 0.766 on average.

The DR curves both for sage and laurel are representative of the drying kinetics of the two species under the test conditions applied. The difference in the drying kinetics found in the two species is due to the different structural characteristics of the biomass processed. Sage leaves have a lower vegetative thickness than laurel leaves, that are also leatherier.

The laurel drying process was stopped after $42 \mathrm{~h}$ from the start, since the smart system detected, for the three tests, MC values on average equal to $30 \%$. This is in accordance with the mean water activity value of the laurel obtained after dehydration (0.766). Considering that, in the literature, there are no sources regarding laurel water activity, the only explanation that can be provided is related to the particular physical-mechanical characteristics of the leaf of this species compared to those of other aromatic herbs. The laurel leaf, in fact, is very leathery and the internal cells offer great resistance to the release of water. Therefore, it would have been necessary to increase the process temperature to reach MC values similar to those obtained in sage. This choice was not made, since it would have been in contrast with many studies present in the literature. Sellami et al. [31], in fact, showed that increasing drying temperature resulted in a significant decrease in the concentration of most volatiles. Additionally, Hadjibagher Kandi et al. [12] state the importance of keeping temperature below $45^{\circ} \mathrm{C}$ to limit the essential oil content losses.

As for sage, on the other hand, the dehydration process ended after $66 \mathrm{~h}$, therefore requiring a drying time higher than $30 \%$ compared to laurel. Furthermore, also in this case, the process was stopped by the smart system when the detected MC variations were negligible. This made it possible to reach an average final MC value of $13 \%$. This corresponds to the water activity value obtained after dehydration (0.350). The process time and temperature used for sage are in agreement with [13]; they dehydrated sage using temperatures of $40{ }^{\circ} \mathrm{C}$ for $77 \mathrm{~h}$ and the drying process was conducted until achieving $10 \%$ of humidity of drying material. As a consequence, the two species have a different "expiration dates", laurel's being shorter than that of sage.

Regarding the polynomial regression analysis applied to the MC values for sage in the three tests, since the $p$-value in Table 2 is less than 0.05 , there is a statistically significant relationship between MC and $\mathrm{t}$ at the $95 \%$ confidence level. The R-squared statistic indicates that the model, as fitted, explains the reported percentage of the variability in MC. The order of the polynomial is appropriate as the $p$-value on the highest order term of the polynomial equals 0.0 .

Table 2. Polynomial regression analysis results for moisture content $\mathrm{MC}$ as a function of time for sage dehydration process in the three tests $\left(\mathrm{S} 1=3 \mathrm{~kg} / \mathrm{m}^{2} ; \mathrm{S} 2=4 \mathrm{~kg} / \mathrm{m}^{2}\right.$ and $\left.\mathrm{S} 3=5 \mathrm{~kg} / \mathrm{m}^{2}\right)$.

\begin{tabular}{|c|c|c|c|c|c|}
\hline Parameter & Estimate & & dard Error & T Statistic & $p$-Value \\
\hline constant & 73.0722 & & 0.01008 & 7246.57 & 0.0000 \\
\hline $\mathrm{t}$ & -1.57941 & & 0.00070 & -2254.84 & 0.0000 \\
\hline$t^{2}$ & 0.00992658 & & 0.00001 & 973.36 & 0.0000 \\
\hline Source & Sum of Squares & Df & Mean Square & F-Ratio & $p$-Value \\
\hline Model & 107,623 & 2 & $53,811.3$ & $14,211,543.51$ & 0.0000 \\
\hline Residual & 1.24953 & 330 & 0.00378645 & & \\
\hline Total & 107,624 & 332 & & & \\
\hline R-squared & $99.9988 \%$ & & & & \\
\hline $\mathrm{MC}$ equation for $\mathrm{S} 1$ : & \multicolumn{5}{|c|}{ MC_S1 $=73.0722-1.57941 \cdot t+0.00992658 \cdot t^{2}$} \\
\hline Parameter & Estimate & & Idard Error & T Statistic & $p$-Value \\
\hline constant & 73.0656 & & 0.01029 & 7101.54 & 0.0000 \\
\hline $\mathrm{t}$ & -1.4671 & & 0.00071 & -2052.77 & 0.0000 \\
\hline$t^{2}$ & 0.00885007 & & 0.00001 & 850.511 & 0.0000 \\
\hline
\end{tabular}


Table 2. Cont.

\begin{tabular}{cccccc}
\hline Source & Sum of Squares & Df & Mean Square & F-Ratio & $p$-Value \\
\hline Model & $97,873.4$ & 2 & $48,936.7$ & $12,414,254.04$ & 0.0000 \\
Residual & 1.30085 & 330 & 0.00394198 & & \\
Total & $97,874.7$ & 332 & & & \\
R-squared & $99.9987 \%$ & & & & \\
MC equation for S2: & & MC_S2 $=73.0656-1.4671 \cdot t+0.00885007 \cdot \mathbf{t}^{2}$ & T Statistic & $p$-Value \\
\hline Parameter & Estimate & Standard Error & 7022.69 & 0.0000 \\
constant & 73.0712 & & 0.01040 & -2102.55 & 0.0000 \\
$t$ & -1.51967 & & 0.00072 & 840.245 & 0.0000 \\
$\mathrm{t}^{2}$ & 0.0088421 & Df & Mean Square & F-Ratio & $p$-Value \\
\hline Source & Sum of Squares & 2 & $54,850.3$ & $13,605,034.19$ & 0.0000 \\
Model & 109,701 & 330 & 0.00403162 & & \\
Residual & 1.33043 & 332 & & & \\
Total & 109,702 & MC_S3 $=73.0712-1.51967 \cdot t+0.0088421 \cdot t^{2}$ &
\end{tabular}

With reference to the simple regression analysis applied to sage DR in the three tests, since the $\mathrm{p}$-value in Table 3 is less than 0.05 , there is a statistically significant relationship between DR and $t$ at the $95.0 \%$ confidence level. The R-squared statistic indicates that the model, as fitted, explains the reported percentage of the variability in DR.

Table 3. Simple regression analysis results for drying rate DR as a function of time for sage dehydration process in the three tests $\left(\mathrm{S} 1=3 \mathrm{~kg} / \mathrm{m}^{2} ; \mathrm{S} 2=4 \mathrm{~kg} / \mathrm{m}^{2}\right.$ and S3 $\left.=5 \mathrm{~kg} / \mathrm{m}^{2}\right)$.

\begin{tabular}{|c|c|c|c|c|c|}
\hline Parameter & Least Squares Estimate & \multicolumn{2}{|c|}{ Standard Error } & T Statistic & $p$-Value \\
\hline intercept & 0.0107142 & \multirow{2}{*}{\multicolumn{2}{|c|}{$\begin{array}{c}0.000003 \\
7.10 \times 10^{-8}\end{array}$}} & 3922.41 & 0.0000 \\
\hline slope & -0.0000667179 & & & -939.53 & 0.0000 \\
\hline Source & Sum of Squares & Df & Mean Square & F-Ratio & $p$-Value \\
\hline Model & 0.000542987 & 1 & 0.000542987 & $882,716.62$ & 0.0000 \\
\hline Residual & $2.02993 \times 10^{-7}$ & 330 & $6.15 \times 10^{-10}$ & & \\
\hline Total & 0.00054319 & 331 & & & \\
\hline R-squared & $99.9626 \%$ & & & & \\
\hline DR equation for S1: & \multicolumn{5}{|c|}{ DR_S1 $=0.0107142-0.0000667179 \cdot \mathrm{t}$} \\
\hline Parameter & Least Squares Estimate & & ard Error & T Statistic & $p$-Value \\
\hline intercept & 0.00994843 & \multirow{2}{*}{\multicolumn{2}{|c|}{$\begin{array}{c}0.000003 \\
7.64 \times 10^{-8}\end{array}$}} & 3386.19 & 0.0000 \\
\hline slope & -0.0000593194 & & & -776.65 & 0.0000 \\
\hline Source & Sum of Squares & Df & Mean Square & F-Ratio & $p$-Value \\
\hline Model & 0.000429237 & 1 & 0.000429 & $603,193.33$ & 0.0000 \\
\hline Residual & $2.34831 \times 10^{-7}$ & 330 & $7.12 \times 10^{-10}$ & & \\
\hline Total & 0.000429472 & 331 & & & \\
\hline R-squared & $99.9453 \%$ & & & & \\
\hline DR equation for S2: & \multicolumn{5}{|c|}{ DR_S2 $=0.00994843-0.0000593194 \cdot t$} \\
\hline Parameter & Least Squares Estimate & & ard Error & T Statistic & $p$-Value \\
\hline intercept & 0.0103152 & \multirow{2}{*}{\multicolumn{2}{|c|}{$\begin{array}{c}0.000002 \\
4.90 \times 10^{-8}\end{array}$}} & 5467.19 & 0.0000 \\
\hline slope & -0.0000594371 & & & -1211.77 & 0.0000 \\
\hline Source & Sum of Squares & Df & Mean Square & F-Ratio & $p$-Value \\
\hline Model & 0.000430944 & 1 & 0.000431 & $1,468,382.14$ & 0.0000 \\
\hline Residual & $9.6849 \times 10^{-8}$ & 330 & $2.93 \times 10^{-10}$ & & \\
\hline Total & 0.00043104 & 331 & & & \\
\hline R-squared & $99.9775 \%$ & & & & \\
\hline DR equation for S3: & \multicolumn{5}{|c|}{ DR_S3 $=0.0103152-0.0000594371 \cdot t$} \\
\hline
\end{tabular}


Tables 4 and 5 show the polynomial regression analysis results respectively for MC and DR as a function time for laurel dehydration process.

Table 4. Polynomial regression analysis results for moisture content $\mathrm{MC}$ as a function of time for laurel dehydration process in the three tests $\left(\mathrm{L} 1=3 \mathrm{~kg} / \mathrm{m}^{2} ; \mathrm{L} 2=4 \mathrm{~kg} / \mathrm{m}^{2}\right.$ and $\left.\mathrm{L} 3=5 \mathrm{~kg} / \mathrm{m}^{2}\right)$.

\begin{tabular}{|c|c|c|c|c|c|}
\hline Parameter & Estimate & \multicolumn{2}{|c|}{ Standard Error } & T Statistic & $p$-Value \\
\hline constant & 54.1725 & \multicolumn{2}{|r|}{0.02741} & 1976.49 & 0.0000 \\
\hline $\mathrm{t}$ & -0.875258 & \multicolumn{2}{|r|}{0.00297} & -294.44 & 0.0000 \\
\hline$t^{2}$ & 0.00879715 & \multicolumn{2}{|r|}{0.00007} & 130.24 & 0.0000 \\
\hline Source & Sum of Squares & Df & Mean Square & F-Ratio & $p$-Value \\
\hline Model & 8491.8 & 2 & 4245.9 & $233,311.76$ & 0.0000 \\
\hline Residual & 3.83986 & 211 & 0.0181984 & & \\
\hline Total & 8495.64 & 213 & & & \\
\hline R-squared & $99.9548 \%$ & & & & \\
\hline MC equation for L1: & \multicolumn{5}{|c|}{ MC_L1 $=54.1725-0.875258 \cdot t+0.00879715 \cdot t^{2}$} \\
\hline Parameter & Estimate & \multicolumn{2}{|c|}{ Standard Error } & T Statistic & $p$-Value \\
\hline constant & 54.6339 & \multicolumn{2}{|r|}{0.01557} & 3509.28 & 0.0000 \\
\hline $\mathrm{t}$ & -0.981658 & \multicolumn{2}{|r|}{0.00169} & -581.39 & 0.0000 \\
\hline$t^{2}$ & 0.0101928 & \multicolumn{2}{|r|}{0.00004} & 265.68 & 0.0000 \\
\hline Source & Sum of Squares & Df & Mean Square & F-Ratio & $p$-Value \\
\hline Model & $10,204.7$ & 2 & 5102.33 & $868,994.45$ & 0.0000 \\
\hline Residual & 1.23889 & 211 & 0.00587153 & & \\
\hline Total & $10,205.9$ & 213 & & & \\
\hline R-squared & $99.9879 \%$ & & & & \\
\hline MC equation for $\mathrm{L} 2$ : & \multicolumn{5}{|c|}{ MC_L2 $=54.6339-0.981658 \cdot t+0.0101928 \cdot t^{2}$} \\
\hline Parameter & Estimate & \multicolumn{2}{|c|}{ Standard Error } & T Statistic & $p$-Value \\
\hline constant & 54.5935 & \multicolumn{2}{|r|}{0.02813} & 1940.74 & 0.0000 \\
\hline $\mathrm{t}$ & -1.05426 & \multicolumn{2}{|r|}{0.00305} & -345.56 & 0.0000 \\
\hline $\mathrm{t}^{2}$ & 0.00990105 & \multicolumn{2}{|r|}{0.00007} & 142.83 & 0.0000 \\
\hline Source & Sum of Squares & Df & Mean Square & F-Ratio & $p$-Value \\
\hline Model & $13,458.6$ & 2 & 6729.28 & $351,040.99$ & 0.0000 \\
\hline Residual & 4.04477 & 211 & 0.0191695 & & \\
\hline Total & $13,462.6$ & 213 & & & \\
\hline R-squared & $99.97 \%$ & & & & \\
\hline MC equation for L3: & \multicolumn{5}{|c|}{ MC_L3 $=54.5935-1.05426 \cdot t+0.00990105 \cdot t^{2}$} \\
\hline
\end{tabular}

Table 5. Polynomial regression analysis results for drying rate DR as a function of time for laurel dehydration process in the three tests $\left(\mathrm{L} 1=3 \mathrm{~kg} / \mathrm{m}^{2} ; \mathrm{L} 2=4 \mathrm{~kg} / \mathrm{m}^{2}\right.$ and $\left.\mathrm{L} 3=5 \mathrm{~kg} / \mathrm{m}^{2}\right)$.

\begin{tabular}{|c|c|c|c|c|c|}
\hline Parameter & Estimate & & lard Error & T Statistic & $p$-Value \\
\hline constant & 0.016539 & \multicolumn{2}{|c|}{0.00021} & 77.44 & 0.0000 \\
\hline$t$ & -0.00178689 & \multicolumn{2}{|c|}{0.00007} & -25.97 & 0.0000 \\
\hline$t^{2}$ & 0.000128877 & \multicolumn{2}{|c|}{0.00001} & 19.78 & 0.0000 \\
\hline$t^{3}$ & -0.00000381636 & \multicolumn{2}{|c|}{$2.28 \times 10^{-7}$} & -16.70 & 0.0000 \\
\hline$t^{4}$ & $3.87457 \times 10^{-8}$ & \multicolumn{2}{|c|}{$2.65 \times 10^{-9}$} & 14.63 & 0.0000 \\
\hline Source & Sum of Squares & Df & Mean Square & F-Ratio & $p$-Value \\
\hline Model & 0.000861156 & 4 & 0.000215289 & 586.36 & 0.0000 \\
\hline Residual & 0.0000763696 & 208 & $3.67161 \times 10^{-7}$ & & \\
\hline Total & 0.000937526 & 212 & & & \\
\hline R-squared & \multicolumn{5}{|l|}{$91.8541 \%$} \\
\hline DR equation for L1: & \multicolumn{5}{|c|}{ DR_L1 $=0.016539-0.00178689 \cdot t+000128877 \cdot t^{2}-0.0000038164 \cdot t^{3}+3.87457 \times 10^{-8} \cdot t^{4}$} \\
\hline
\end{tabular}


Table 5. Cont.

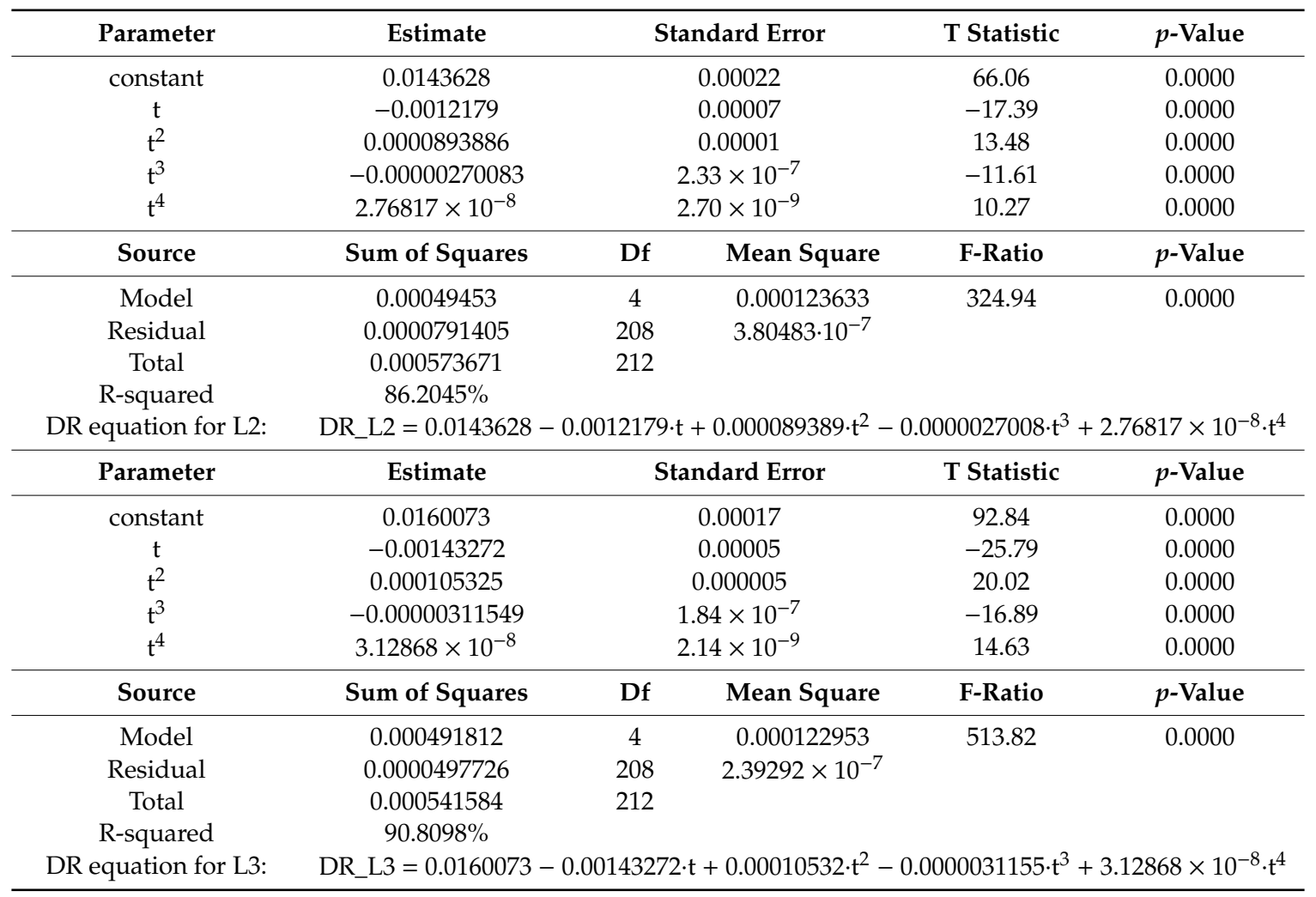

ANOVA results on MC values for sage taken every $6 \mathrm{~h}$ during the dehydration process do not show statistically significant differences between the three tests under study (Table 6).

Table 6. Analysis of variance results on moisture content values every six hours (MC) for sage dehydration process in the three tests $\left(\mathrm{S} 1=3 \mathrm{~kg} / \mathrm{m}^{2} ; \mathrm{S} 2=4 \mathrm{~kg} / \mathrm{m}^{2}\right.$ and $\left.\mathrm{S} 3=5 \mathrm{~kg} / \mathrm{m}^{2}\right)$. Data are means $\pm \operatorname{SD}(\mathrm{n}=3)$.

\begin{tabular}{cccccc}
\hline Time & S1 & S2 & S3 & $p$-Value & Significance $^{\mathbf{1}}$ \\
\hline $\mathrm{t}_{0}$ & $72.7 \pm 1.9$ & $72.7 \pm 1.3$ & $72.7 \pm 2.1$ & 1.0000 & n.s. \\
$\mathrm{t}_{6}$ & $63.9 \pm 2.4$ & $64.5 \pm 1.9$ & $64.2 \pm 1.9$ & 0.9379 & n.s. \\
$\mathrm{t}_{12}$ & $55.5 \pm 1.9$ & $56.7 \pm 1.4$ & $56.0 \pm 1.7$ & 0.6860 & n.s. \\
$\mathrm{t}_{18}$ & $47.8 \pm 2.2$ & $49.5 \pm 2.5$ & $48.5 \pm 1.3$ & 0.6206 & n.s. \\
$\mathrm{t}_{24}$ & $40.8 \pm 2.0$ & $42.9 \pm 2.4$ & $41.6 \pm 1.7$ & 0.4942 & n.s. \\
$\mathrm{t}_{30}$ & $36.4 \pm 2.3$ & $37.0 \pm 2.0$ & $35.4 \pm 1.6$ & 0.3542 & n.s. \\
$\mathrm{t}_{36}$ & $29.0 \pm 2.0$ & $31.7 \pm 2.0$ & $29.8 \pm 2.2$ & 0.3285 & n.s. \\
$\mathrm{t}_{42}$ & $24.2 \pm 2.2$ & $27.0 \pm 2.0$ & $24.8 \pm 2.5$ & 0.3232 & n.s. \\
$\mathrm{t}_{48}$ & $20.1 \pm 1.9$ & $23.0 \pm 1.0$ & $20.5 \pm 1.9$ & 0.1388 & n.s. \\
$\mathrm{t}_{54}$ & $16.7 \pm 1.5$ & $19.6 \pm 1.8$ & $16.8 \pm 2.1$ & 0.1582 & n.s. \\
$\mathrm{t}_{60}$ & $14.0 \pm 2.0$ & $16.9 \pm 2.2$ & $13.7 \pm 2.2$ & 0.1986 & n.s. \\
$\mathrm{t}_{60}$ & $12.1 \pm 2.2$ & $14.8 \pm 2.2$ & $11.3 \pm 1.5$ & 0.1572 & n.s. \\
\hline \multicolumn{7}{c}{ n.s. $=$ not significant. } &
\end{tabular}

ANOVA results on MC values for laurel taken every $6 \mathrm{~h}$ during the dehydration process (Table 7) show statistically significant differences between the three biomass densities in the last part of the process; in particular at $t_{30}, t_{36}$ and $t_{42}$, (corresponding to the MC value registered after 30,36 and $42 \mathrm{~h}$ from the beginning of the process). 
Table 7. Analysis of variance results on moisture content values every six hours (MC) for laurel dehydration process in the three tests $\left(\mathrm{L} 1=3 \mathrm{~kg} / \mathrm{m}^{2} ; \mathrm{L} 2=4 \mathrm{~kg} / \mathrm{m}^{2}\right.$ and $\left.\mathrm{L} 3=5 \mathrm{~kg} / \mathrm{m}^{2}\right)$. Data are means $\pm \mathrm{SD}(\mathrm{n}=3)$. Values in each row with different letters are significantly different from one another at $p<0.05$ (Tukey's test).

\begin{tabular}{cccccc}
\hline Time & L1 & L2 & L3 & $p$-Value & Significance $^{\mathbf{1}^{\prime}}$ \\
\hline $\mathrm{t}_{0}$ & $55.0 \pm 1.4$ & $55.0 \pm 1.3$ & $55.0 \pm 2.0$ & 0.9986 & n.s. \\
$\mathrm{t}_{6}$ & $49.3 \pm 1.7$ & $49.1 \pm 1.2$ & $48.7 \pm 1.7$ & 0.8789 & n.s. \\
$\mathrm{t}_{12}$ & $45.1 \pm 1.1$ & $44.3 \pm 1.6$ & $43.5 \pm 1.6$ & 0.4040 & n.s. \\
$\mathrm{t}_{18}$ & $41.1 \pm 1.2$ & $40.2 \pm 0.8$ & $38.8 \pm 1.5$ & 0.1123 & n.s. \\
$\mathrm{t}_{24}$ & $38.4 \pm 1.9$ & $37.0 \pm 1.0$ & $35.0 \pm 1.2$ & 0.0683 & n.s. \\
$\mathrm{t}_{30}$ & $35.9 \pm 1.8 \mathrm{a}$ & $34.3 \pm 1.4 \mathrm{ab}$ & $31.6 \pm 1.4 \mathrm{~b}$ & 0.0334 & \\
$\mathrm{t}_{36}$ & $34.1 \pm 1.9 \mathrm{a}$ & $32.5 \pm 1.7 \mathrm{ab}$ & $29.4 \pm 1.9 \mathrm{~b}$ & 0.0479 & \\
$\mathrm{t}_{42}$ & $32.8 \pm 1.4 \mathrm{a}$ & $31.4 \pm 1.6 \mathrm{ab}$ & $28.0 \pm 1.7 \mathrm{~b}$ & 0.0207 & \\
\hline \multicolumn{7}{c}{ n.s. $=$ not significant. }
\end{tabular}

\subsection{Microbiological Aspects}

The results of the microbiological analyses are reported in Figure 6. The drying processes completely eliminated members of Enterobacteriacea family, yeasts and molds from sage, since their levels were below the detection limit (reported as zero in the graphic), independently on the biomass density applied (Figure 6A). TMM were still detected after drying, but the thermal process consistently decreased their levels (until 3.47-3.74 CFU/g). Even though no statistical differences were registered among the biomass densities during drying, the trend observed is that microbial mortality decreased when the biomass density increased inside the drying chamber.

The same drying process applied to laurel indicated how the different leaf structure influenced microbial survival. In this case, all four microbial groups object of investigation showed a higher resistance than those searched in sage, because their levels were clearly detectable (Figure 6B). The drying process did not significantly reduce the levels of TMM and molds when the biomass density was $5 \mathrm{~kg} / \mathrm{m}^{2}$. With laurel leaves, it is undoubtedly shown that the biomass drying density influenced microbial death kinetics, since the viability of all populations registered at $3 \mathrm{~kg} / \mathrm{m}^{2}$ was at the lowest levels and increased with biomass drying density.

(A)

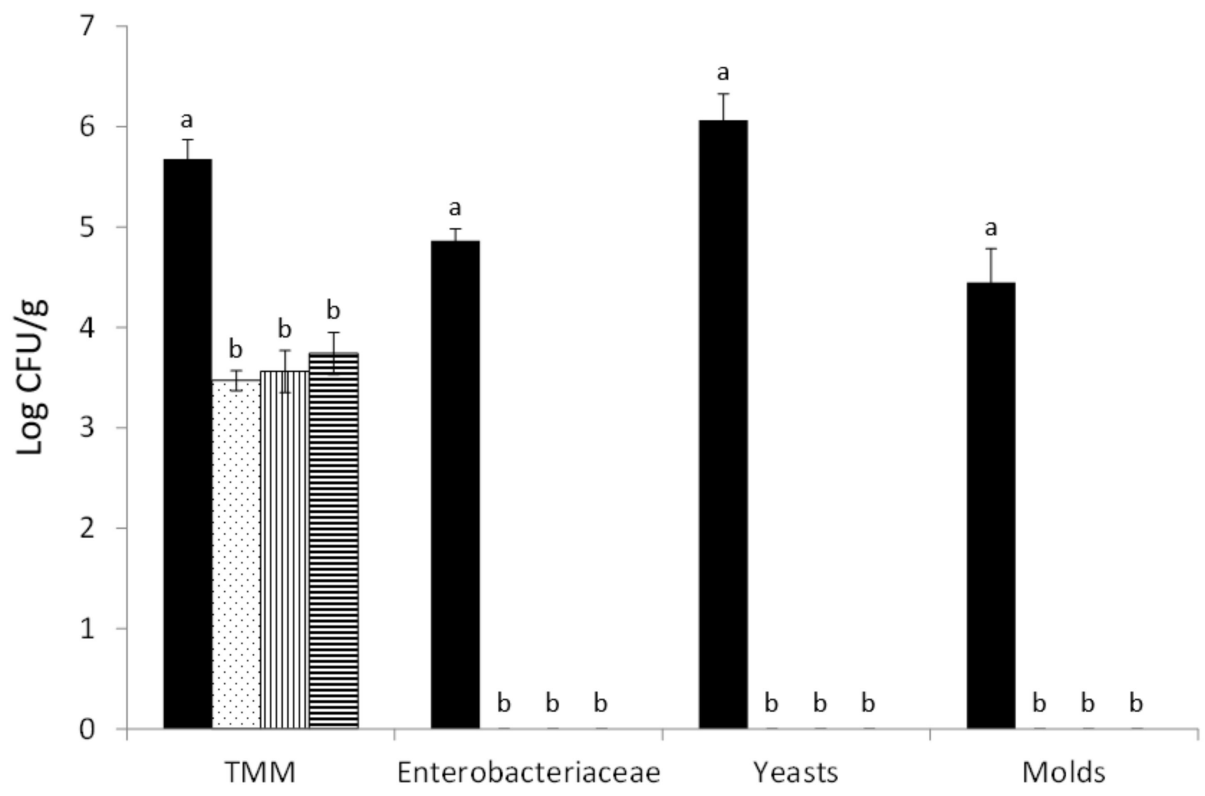

Figure 6. Cont. 
(B)

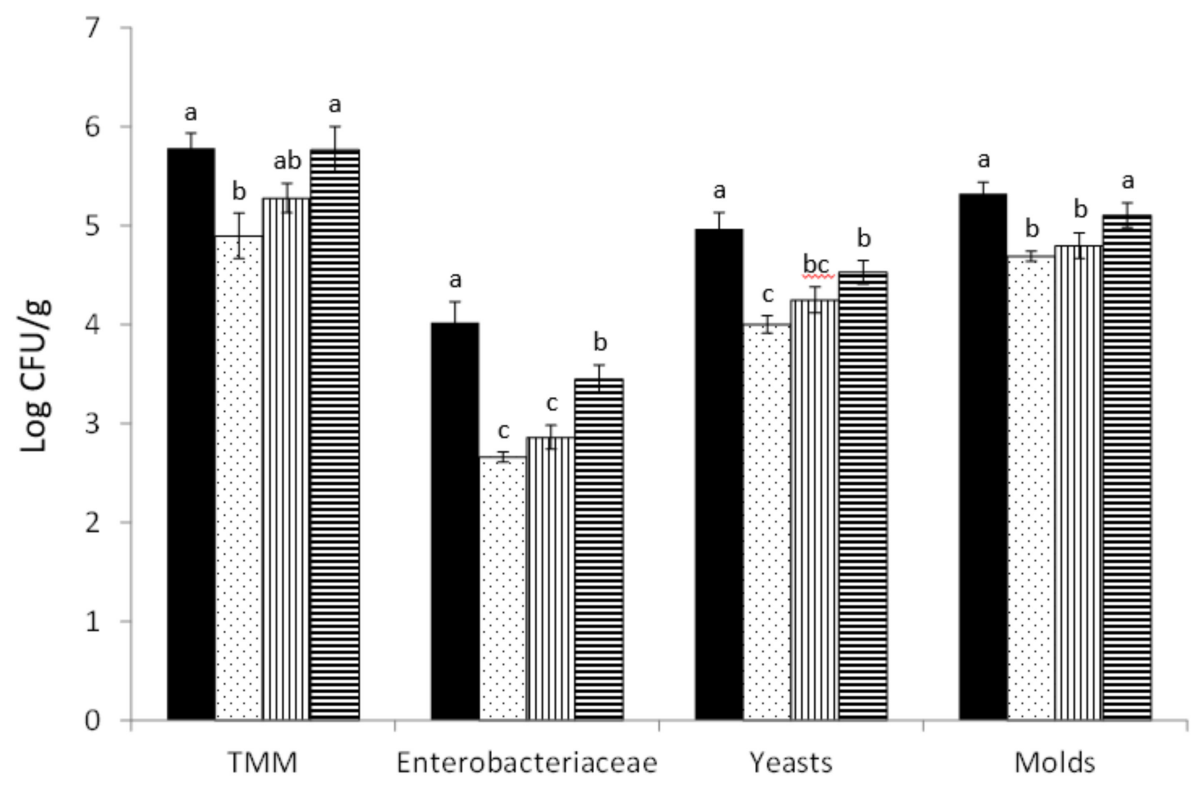

Figure 6. Microbial loads of aromatic herbs subjected to drying. (A), sage; (B), laurel.

The results of TMM in our study are little below the levels of total bacterial counts at 22 and $37^{\circ} \mathrm{C}$ detected by [32], where the authors analyzed different dried herbs, including sage, cultivated in family-managed fields. The differences could not be explained in terms of drying process, since the drying process reported in [32] consisted of a ventilated drying at $40{ }^{\circ} \mathrm{C}$ for $24 \mathrm{~h}$, but the information about the load density of the leaves was not reported. The same authors also reported for sage total coliforms, which are part of Enterobacteriaceae family, values below $104 \mathrm{CFU} / \mathrm{g}$. In [33], several potential pathogenic species were found, including Yersinia intermedia, Shigella spp. and Enterobacter spp. in several commercialized dried spices and herbs, highlighting the importance of acquiring information on the efficacy of the drying process. Considering that the microbiological quality of commercialized herbs can influence the final safety of different formulated foods [34], the drying process assumes a relevant role during the processing of fresh herbs, even though the conditions applied during conservation are of paramount importance [35].

To our knowledge, this is the first work performed on the microbiological characterization of laurel leaves. Our data clearly show how these leaves exert a protective effect on bacteria, yeasts and molds, highlighting the importance of acquiring information on the microbiological characteristics of herbs used in food formulation and preparation. The disappearance of all microbial groups from sage is easily explained by the very low water activity values registered for the species after the dehydration process, which was in the range $0.335-0.377$ for the different biomass densities. Water activity represents an intrinsic parameter of paramount importance for the development of microorganisms in food. This factor greatly influences microbial thermal resistance; thus, low moisture foods are particularly hostile for microbial survival [36]. On the contrary, laurel structure did not allow a consistent removal of water, determining the higher survival of bacteria and fungi in comparison to sage. However, unlike sage, laurel is not commonly consumed raw and generally undergoes a thermal treatment before consumption, such as boiling (e.g., for the preparation of chestnuts boiled in water flavored with fennel seeds or laurel leaves) [37] or roasting (when added to meat) [38].

\section{Conclusions}

The smart system tested has provided valid decision support during the entire drying process, allowing the precise monitoring of the evolution of the biomass moisture loss and drying rate. It allowed us to stop the drying process at time " $\mathrm{t}$ " in which the biomass gave negligible weight variations-that is, at the temperature of $40^{\circ} \mathrm{C}$ it was no longer possible to lower MC for both species. This made it possible to limit the loss of volatile and phenolic compounds of the dried product. In fact, in the 
literature it is well known that very long drying times and temperatures above $40{ }^{\circ} \mathrm{C}$ lead to a reduction in the quality of the final product. The two species examined, after drying at the same temperature, achieved a different microbial stability, higher in sage than in laurel. This difference can be attributed to the different structural characteristics of the leaves of the two species, which influence the quantity of bound water present in the plant tissues. The three different biomass densities employed $(3,4$ and $5 \mathrm{~kg} / \mathrm{m}^{2}$ ) did not provide significant differences in the drying process for sage. Statistically significant differences among the three tests were found for laurel in the final part of the process. It follows that biomass density up to $5 \mathrm{~kg} / \mathrm{m}^{2}$ is not a limiting factor in the duration of the process. Further tests with higher biomass densities will be necessary in order to identify the biomass density beyond which the duration of the drying process is higher than that obtained for the two species. Monitoring and controlling the process also allows us to identify any critical points during drying, including the malfunction of the drying chamber, with temperature variations inside, such as to compromise the product in the event of temperatures above $40^{\circ} \mathrm{C}$, or to be carried out for very long process times in the event of temperatures below $40^{\circ} \mathrm{C}$. The microbial loads of the aromatic herbs after drying was influenced by the different leaf structures of the species; in particular, with laurel leaves, microbial survival increased with increasing biomass density. Finally, with the drying method adopted, the two species under consideration showed a different microbial stability and, consequently, will have a different shelf life, longer for sage than for laurel.

Author Contributions: Conceptualization, P.C.; methodology, P.C.; software, S.O.; validation, S.O. and L.S.; formal analysis, M.V. and L.S.; investigation, P.C. and S.O.; resources, P.C. and L.S.; data curation, S.O. and R.G.; writing — original draft preparation, M.V. and R.G.; writing—review and editing, M.V.; visualization, R.G.; supervision, M.V. and L.S.; project administration, P.C. All authors have read and agreed to the published version of the manuscript.

Funding: This research received no external funding.

Conflicts of Interest: The authors declare no conflict of interest.

\section{References}

1. Gunjan, M.; Naing, T.W.; Saini, S.R.; Ahmad, A.; Naidu, J.R.; Kumar, I. Marketing trends and future prospects of herbal medicine in the treatment of various disease. World J. Pharm. Res. 2015, 4, 132-155.

2. Chandrasekara, A.; Shahidi, F. Herbal beverages: Bioactive compounds and their role in disease risk reduction-A review. J. Tradit. Complement Med. 2018, 8, 451-458. [CrossRef] [PubMed]

3. Serraino, M.; Thompson, L.U. The effect of flaxseed supplementation on the initiation and promotional stages of mammary tumorigenesis. Nutr. Cancer 1992, 17, 153-159. [CrossRef]

4. Ignacimuthu, S.; Ayyanar, M.; Silverman, S.K. Ethnobotanical investigations among tribes in Madurai district of Tamil Nadu (India). J. Ethnobiol. Ethnomed. 2006, 2, 25. [CrossRef] [PubMed]

5. Elujoba, A.A.; Odeleye, O.M.; Ogunyemi, C.M. Traditional medicine development for medical and dental primary health care delivery system in Africa. Afr. J. Tradit. Complement. Altern. Med. 2005, 2, 46-61. [CrossRef]

6. El-Sayed, S.M.; Youssef, A.M. Potential application of herbs and spices and their effects in functional dairy products. Heliyon 2019, 5, e01989. [CrossRef]

7. Gottardi, D.; Bukvicki, D.; Prasad, S.; Tyagi, A.K. Beneficial effects of spices in food preservation and safety. Front. Microbiol. 2016, 7, 1394. [CrossRef]

8. ISMEA. Piante Officinali in Italia: Un'istantanea Della Filiera e dei Rapporti tra i Diversi Attori. 2013. Available online: https://www.ismea.it (accessed on 17 June 2020).

9. Basso, F. Piante Officinali, Aromatiche e Medicinali. Aspetti Bioagronomici Aromatici e Fitoterapeutici; Editor Pitagora: Bologna, Italy, 2009; ISBN 9788837117320.

10. Bimbenet, J.J.; Duquenoy, A.; Trystram, G. Genie des Procedes Alimentaires: Des Bases Aux Applications, 2nd ed.; Dunod: Paris, France, 2002; ISBN 13-978-2100763696.

11. Diaz-Maroto, M.C.; Perez-Coello, M.S.; Cabezudo, M.D. Effect of drying method on the volatiles in bay leaf (Laurus nobilis L.). J. Agric. Food Chem. 2002, 50, 4520-4524. [CrossRef] 
12. Hadjibagher Kandi, M.N.; Sefidkon, F. The influense of drying methods on essential oil content and composition of Laurus nobilis L. J. Essent. Oil Bear. Plant 2011, 14, 302-308. [CrossRef]

13. Sadowska, U.; Kopeć, A.; Kourimska, L.; Zarubova, L.; Kloucek, P. The effect of drying methods on the concentration of compounds in sage and thyme. J. Food Process. Pres. 2017, 41, e13286. [CrossRef]

14. El-Mesery, H.S.; Mwithiga, G. Mathematical modelling of thin layer drying kinetics of onion slices hot-air convection, infrared radiation and combined infrared-convection drying. Adv. Environ. Biol. 2014, 8, 1-19.

15. Kudra, T. Energy aspects in drying. Dry. Technol. 2004, 22, 917-932. [CrossRef]

16. Motevali, A.; Minaei, S.; Banakar, A.; Ghobadian, B.; Khoshtaghaza, M.H. Comparison of energy parameters in various dryers. Energ. Convers. Manag. 2014, 87, 711-725. [CrossRef]

17. Sarsavadia, P.N. Development of a solar-assisted dryer and evaluation of energy requirement for the drying of onion. Renew. Energy 2007, 32, 2529-2547. [CrossRef]

18. Chakraborty, R.; Tilottama, D. Drying protocols for traditional medicinal herbs: A critical review. Int. J. Eng. Technol. 2016, 4, 1-8.

19. Rodriguez, J.; Melo, E.C.; Mulet, A.; Bon, J. Optimization of the antioxidant capacity of thyme (Thymus vulgaris L.) extracts: Management of the convective drying process assisted by power ultrasound. J. Food Eng. 2013, 119, 793-799. [CrossRef]

20. Ratti, C. Hot air and freeze-drying of high-value foods: A review. J. Food Eng. 2001, 49, 311-319. [CrossRef]

21. Fennell, C.W.; Light, M.E.; Sparg, S.G.; Stafford, G.I.; Van Staden, J. Assessing African medicinal plants for efficacy and safety: Agricultural and storage practices. J. Ethnopharmacol. 2004, 95, 113-121. [CrossRef]

22. Tunde-Akintunde, T.Y.; Ogunlakin, G.O. Influence of drying conditions on the effective moisture diffusivity and energy requirements during the drying of pretreated and untreated pumpkin. Energ. Convers. Manag. 2011, 52, 1107-1113. [CrossRef]

23. Antal, T.; Figiel, A.; Kerekes, B.; Sikolya, L. Effect of drying methods on the quality of the essential oil of spearmint leaves (Mentha spicata L.). Dry. Technol. 2011, 29, 1836-1844. [CrossRef]

24. Müller, J.; Reisinger, G.; Kisgeci, J.; Kotta, E.; Tesic, M.; Mühlbauer, W. Development of a greenhouse-type solar dryer for medicinal plants and herbs. Solar Wind Technol. 1989, 6, 523-530. [CrossRef]

25. Aiello, G.; Giovino, I.; Vallone, M.; Catania, P.; Argento, A. A decision support system based on multisensor data fusion for sustainable greenhouse management. J. Clean. Prod. 2018, 172, 4057-4065. [CrossRef]

26. Vallone, M.; Aiello, G.; Sciortino, R.; Catania, P. First results of iButton loggers and infrared camera application inside a greenhouse. Acta Hortic. 2017, 1170, 283-291. [CrossRef]

27. Catania, P.; Vallone, M.; Farid, A.; De Pasquale, C. Effect of $\mathrm{O}_{2}$ control and monitoring on the nutraceutical properties of extra virgin olive oils. J. Food Eng. 2016, 169, 179-188. [CrossRef]

28. Tuttolomondo, T.; La Bella, S.; Leto, C.; Gennaro, M.; Calvo, R.; D’Asaro, F. Biotechnical characteristics of root systems in erect and prostrate habit rosmarinus officinalis L. accessions grown in a Mediterranean climate. Chem. Eng. Trans. 2017, 58, 769-774. [CrossRef]

29. Doymaz, I.; Karasu, S. Effect of air temperature on drying kinetics, colour changes and total phenolic content of sage leaves (Salvia officinalis). Qual. Assur. Saf. Crop. 2018, 10, 269-276. [CrossRef]

30. Demir, V.; Gunhan, T.; Yagcioglu, A.K.; Degirmencioglu, A. mathematical modelling and the determination of some quality parameters of air-dried bay leaves. Biosyst. Eng. 2004, 88, 325-335. [CrossRef]

31. Sellami, I.H.; Wannes, W.A.; Bettaieb, I.; Berrima, S.; Chahed, T.; Marzouk, B.; Limam, F. Qualitative and quantitative changes in the essential oil of Laurus nobilis L. leaves as affected by different drying methods. Food Chem. 2011, 126, 691-697. [CrossRef]

32. Vitullo, M.; Ripabelli, G.; Fanelli, I.; Tamburro, M.; Delfine, S.; Sammarco, M.L. Microbiological and toxicological quality of dried herbs. Lett. Appl. Microbiol. 2011, 52, 573-580. [CrossRef]

33. Sospedra, I.; Soriano, J.M.; Mañes, J. Assessment of the microbiological safety of dried spices and herbs commercialized in Spain. Plant Food. Hum. Nutr. 2010, 65, 364-368. [CrossRef]

34. Witkowska, A.M.; Hickey, D.K.; Alonso-Gomez, M.; Wilkinson, M.G. The microbiological quality of commercial herb and spice preparations used in the formulation of a chicken supreme ready meal and microbial survival following a simulated industrial heating process. Food Control 2011, 22, 616-625. [CrossRef]

35. Santos, J.; Herrero, M.; Mendiola, J.A.; Oliva-Teles, M.T.; Ibáñez, E.; Delerue-Matos, C.; Oliveira, M.B.P.P. Fresh-cut aromatic herbs: Nutritional quality stability during shelf-life. LWT-Food Sci. Technol. 2014, 59, 101-107. [CrossRef] 
36. Syamaladevi, R.M.; Tang, J.; Villa-Rojas, R.; Sablani, S.; Carter, B.; Campbell, G. Influence of water activity on thermal resistance of microorganisms in low-moisture foods: A review. Compr. Rev. Food Sci. Food Saf. 2016, 15, 353-370. [CrossRef]

37. Bellini, E. The chestnut and its resources: Images and considerations. Acta Hortic. 2005, 693, 85-96. [CrossRef]

38. Alejo-Armijo, A.; Altarejos, J.; Salido, S. Phytochemicals and biological activities of laurel tree (Laurus nobilis). Nat. Prod. Commun. 2017, 12, 743-757. [CrossRef] [PubMed]

(C) 2020 by the authors. Licensee MDPI, Basel, Switzerland. This article is an open access article distributed under the terms and conditions of the Creative Commons Attribution (CC BY) license (http://creativecommons.org/licenses/by/4.0/). 